\title{
TITLE:
}

\section{A DISTRIBUTION STUDY OF THE OCTOCORALLIA OF OREGON}

AUTHOR(S):

Belcik, Francis P.

\section{CITATION:}

Belcik, Francis P.. A DISTRIBUTION STUDY OF THE OCTOCORALLIA OF OREGON. PUBLICATIONS OF THE SETO MARINE BIOLOGICAL LABORATORY 1977, 24(1-3): 49-52

ISSUE DATE:

1977-11-30

URL:

http://hdl.handle.net/2433/175960

RIGHT: 


\title{
A DISTRIBUTION STUDY OF THE OCTOCORALLIA OF OREGON
}

\author{
Francis P. BELGIK \\ Department of Biology, East Carolina University, Greenville, \\ North Carolina 27834, U.S.A.
}

With Text-figure 1 and Tables $1-2$

\section{Introduction:}

The purpose of this report was to identify the species of octocorals, note their occurrence or distribution and also their numbers.

The Octocorals of this report were collected mainly from the Oregonian Region. The majority of specimens were collected by the Oceanography Department of Oregon State University at depths below 86 meters." A few inshore species were collected at various sites along the Oregon Coast (see Fig. 1). Only two species were found in the Intertidal Zone; the bulk of the Octocoral fauna occur offshore in deeper water.

Most of the deep water specimens are now deposited in the Oceanography Department of Oregon State University in Corvallis, Oregon. The inshore specimens have remained in my personal collection.

\section{Identification Methods:}

No references have been published for the soft corals of Oregon; although collections have possibly been made in the past. Helpful sources for identification, after the standard methods of corrosion, and spicule measurements have been made are: Bayer, 1961; Hickson, 1915; Kükenthal, 1907, and 1913; Nutting, 1909 and 1912; Utinomi, 1960, 1961, and 1966 and Verrill, 1922. Specimens of Umbellula were not subjected to corrosion nor separated according to species at this time.

\section{Collection Sites:}

Inshore collection sites have been made mainly at Boiler Bay; Depoe Bay; Newport; Sunset Bay, and the three coves of Cape Arago State Park and Cape Blanco. Various sites in deeper marine water occur off the Mid-Oregon Region(Fig. 1) between longitudes $124^{\circ} \mathrm{W}$ latitude $44^{\circ} \mathrm{N}$ and $128^{\circ} \mathrm{W} 44^{\circ} \mathrm{N}$.

Publ. Seto Mar. Biol. Lab., XXIV (1/3), 49-52, 1977

(Article 7) 


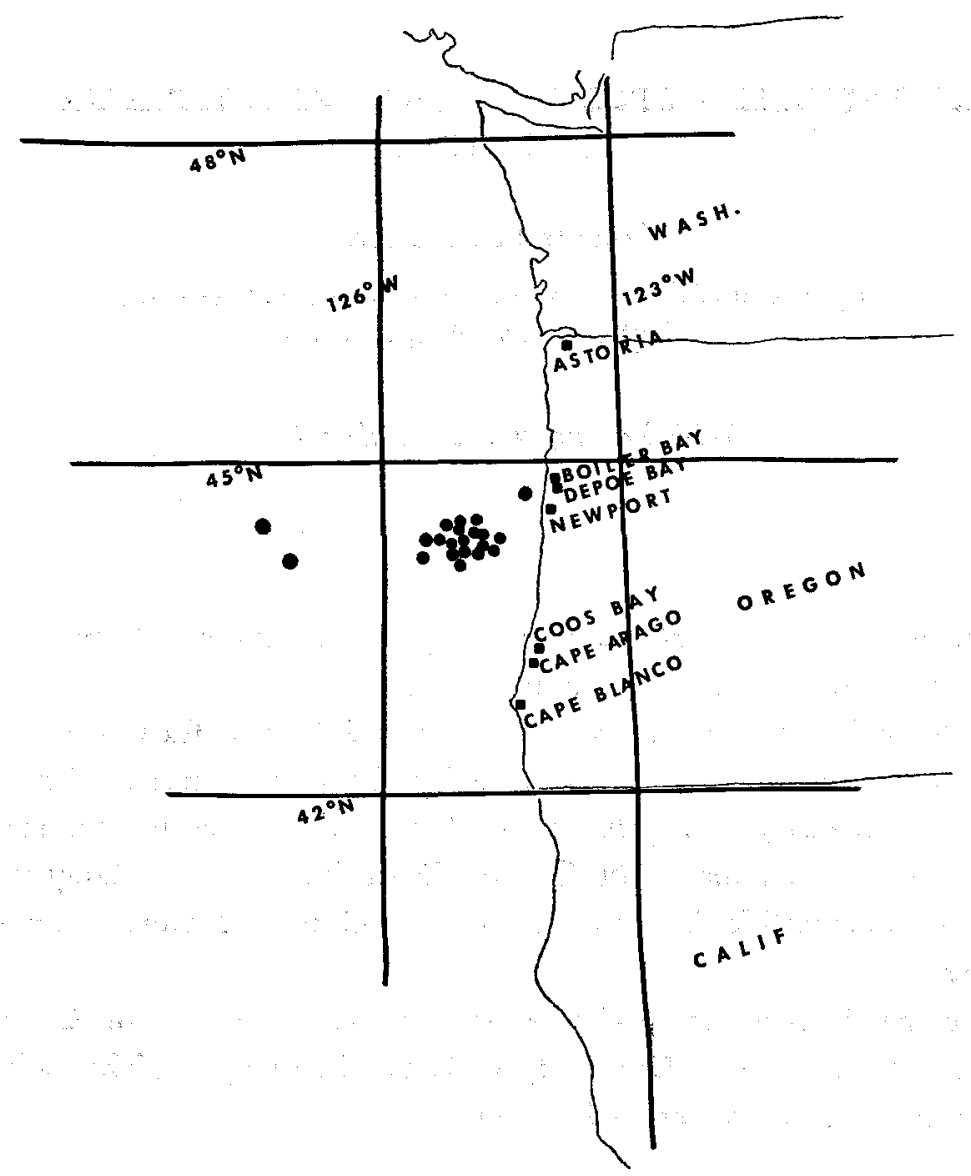

Fig. 1.

\section{Discussion:}

Results of the five year study, has been to gain information on numbers of species and specimens, depth and zonation, locality and bottom type habitats.

The soft corals identified show a relationship to those of the Californian Coast as well as to those of Japan and the Atlantic Coast of North America. According to number, the most common species are the pennatulids, Balticina pacifica and Stylatula elongata with the sea anemone, Stephanauge sp. and also the inshore alcyonarian, Gersemia rubiformis, collected at Cape Blanco and also in extensive beds with Epizoanthus sp. at Simpson Reef near Cape Arago State Park.

Some confusion remains over the identification of certain forms; the inshore form commonly referred to as "Clavularia" is possibly an immature specimen of Gersemia fruticosa (Sars, 1960), collected at Boiler Bay, Sunset Bay near Cape Arago State Park and Cape Blanco. It agrees in habit of growth, small clustered polyps and in spicules. The nudibranch, Tritonia festiva is usually found near by and is possibly a predator. However, a species of Clavularia does occur offshore in 1,530 
Table 1. Octocorals grouped according to depth in meters

I. Intertidal

Gersemia fruticosa

Gersemia rubiformis

II. Shallow water, neritic or offshore

(5-200 meters)

Gersemia rubiformis (Shallows)

Psammogorgia spauldingi (Shallows)

Ptilosarcus gurneyi 86 meters

Stenogorgia kofoidi 101-106 M, 126

M, $138 \mathrm{M}$

Stylatula elongata 128-146 M, 165-

$183 \mathrm{M}, 190 \mathrm{M}$

Scleroptilum sp. $109 \mathrm{M}$

III. 500 to 1,000 meters

Balticina pacifica $549-640$ M, $800 \mathrm{M}$

Pennatula phosphorea $861 \mathrm{M}$

Anthoptilum grandiflorum $861 \mathrm{M}$
Umbellula spp. 823-914 M, 861 M, $1000 \mathrm{M}$

Funiculina armata $750 \mathrm{M}, 800 \mathrm{M}$, $861 \mathrm{M}$

Acanella sp. $832 \mathrm{M}$

Virgularia sp. $800 \mathrm{M}$

IV. 1,000 to 2,000 meters

Balticina pacifica 1,335-1,372 M,

$1,530 \mathrm{M}$

Clavularia sp. 1,530 M

Helicoptilum rigidum $1,829 \mathrm{M}$

Radicipes sp. 2,000 M

V. 2,000 to 3,000 meters

Plumarella sp. 2,086 M

Pennatula sp. $2,600 \mathrm{M}$

Kophobelemnon hispidum 2,800 M

Table 2. Systematic list of Oregon octocorals

\section{Subclass Octocorallia \\ Order Stolonifera \\ Family Clavulariidae \\ 1. Clavularia sp.}

Order Alcyonacea

Family Nephtheidae

2. Gersemia rubiformis (Ehrenberg, 1834)

3. Gersemia furticosa (Sars, 1860)

Order Gorgonacea

Suborder Holaxonia

Family Plexauridae

4. Euplexaura marki Kuth

5. Psammogorgia spauldingi Nutting

Family Gorgoniidae

6. Stenogorgia kofoidi Nutting

Family Primnoidae

Subfamily Primnoinae

7. Plumarella or Thouarella sp.

Family Chrysogorgiidae

Subfamily Lepiogdorgiinae

8. Radicipes (Lepidogorgia) sp.

Family Isididae

Subfamily Keratoisidinae

9. Acanella sp.
Order Pennatulacea

Suborder Sessiliflorae

Family Kophobelemnidae

10. Kophobelemnon hispidum

11. Kophobelemnon sp. (possibly immature)

Family Anthoptilidae

12. Anthoptilum grodiflorum (Verrill)

13. Anthoptilum sp. (possibly immature)

Family Funiculinidac

14. Funiculina armata Verrill

Family Protoptilidae

15. Helicoptilum rigidum

Family Scleroptilidae

16. Scleroptilum sp.

Family Umbellulidae

17. Umbellula spp.

Suborder Subselliflorae

Family Virgulariidae

Subfamily Virgulariinae

18. Virgularia sp.

19. Stylatula elongata

Subfamily Balticininae

20. Balticina pacifica

Family Pennatulidae

21. Pennatula phosphorea

22. Ptilosarcus gurneyi 
meters with the tropical black coral Antipathes sp. on old pogonophoran tubes and has the rambling, connected, single large polyp habit of growth and different types of spicules.

Interestingly, the octocoral fauna also shows zonation (Table 1) according to depth of water. More than twenty species of octocorals occur (see systematic list, Table 2) in this area, 1 Stolonifera member, 2 Alcyonacea, 6 genera of Gorgonacea, and 11 genèrà of pennatulids.

\section{Acknowledgements:}

I wish to thank Dr. James E. McCauley and Dr. Andrew G. Carey, Jr. for permission to examine, study and photograph the specimens. Special thanks are due also to Mrs. Patsy W. Sawyer for typing of the manuscript and to Dr. Patricia A. Daugherty and Dr. Edward P. Ryan for reading the manuscript.

\section{REFERENCES}

Bayer, Frederick M. 1956. Octocorallia. In: Moore, Raymond C. (ed.) Treatise on Invertebrate Palcontology, Part F, Coelenterata, p. 166-231, Geol. Soc. America and University of Kansas Press.

Bayer, Frederick M. 1961. The Shallow-water Octocorallia of the West Indian Region. A Manual for Marine Biologists. Martinus Nijhoff, The Hague, Netherlands.

Deichmann, Elizabeth. 1936. The Alcyonaria of the Western Part of the Atlantic Ocean: Mem. Mus. Comp. Zool. Harvard. Vol. 53, p. 1-317.

Hickson, S.J. 1915. Some Alcyonaria and a Stylaster from the West Coast of North America. Proc. Zool. Soc. London for 1915 (4), pp. 541 $<557,5$ figs. 1 pl.

Kükenthal, Willy: 1907. Versuch einer Revision der Alcyonarien. II. Die Familie der Nephthyiden. 3 Teil. Die Gattungen Eunephthya Verrill and Gersemia Marenzeller. Zool. Jahrb., Abt. f. Syst., vol. 24, pt. 5, pp. 329-390.

Kükenthal, Willy. 1913. Uber die Alcyonarian Fauna Californiens. Zool. Jahrb., Abt. f. Syst., vol. 35, pp. 219-270.

Nutting, Charles C. 1909. Alcyonaria of the Californian Coast. Proceedings U.S. National Museum, Washington, D.C., vol. 35 , No. 1658 , pp. $681-727.8$ pls.

Nutting, Charles C. 1912. Descriptions of the Alcyonaria Collected by the U.S. Fisheries Steamer "Albatross," mainly in Japanese Waters, During 1906. Proceedings U.S. National Museum, Washington, D.C., vol. 43 , No. 1923 , pp. 1-104, plates 1-21.

Utinomi, Huzio. 1960. Noteworthy Octocorals collected off the Southwest Coast of Kii Peninsula, Middle Japan. Part I, Stolonifera and Alcyonacea. Publ. Seto Mar. Biol. Lab. Sirahama, Japan. 8 (1), p. 1-25, 9 figs. 2 pls.

Utinomi, Huzio. 1960. A Revision of the Nomenclature of the Family Nephtheidae (Octocorallia: Alcyonacea) I. The Genera Capnella, Scleronephthya and Chondronephthya (n.g.). Publ. Seto Mar. Biol. Lab. Sirahama, Japan. 8(1), p. 27-40, 5 figs.

Utinomi, Huzio. 1961. Noteworthy Octocorals collected off the Southwest Coast of Kii Peninsula, Middle Japan. Part II, Telestacea, Gorgonacea and Pennatulacea. Publ. Seto Mar. Biol. Lab. Sirahama, Japan. 9 (1), p. 197-228, 14 figs. 4 pls.

Utinomi, Huzio. 1961. A Rezision of the Nomenclature of the Family Nephtheidae (Octocorallia: Alcyonacea) II. The Boreal Genera Gersemia, Duva, Drifa and Pseudodrifa (n.g.). Publ. Seto Mar. Biol. Lab. Sirahama, Japan. 9(1), p. 229-246, 6 figs. 1 pl.

Utinomi, Huzio. 1966. A Revision of the Nomenclature of the Family Nephtheidae (Octocorallia: Alcyonacea) III. A New Genus Coronephthya for a Unique Octocoral previously assigned to the Genera Dendronephthya or Stereonephthya. Publ. Seto Mar. Biol. Lab. Sirahama, Japan. 14(3), p. 207-217, 3 figs. 1 pl.

Verrill, Addison Emery. 1922. Alcyonaria and Actinaria. Rept. Canadian Arctic Exped. 1913-1918, 8 (G), p. 1-164, pls. 19-31. 